\title{
First study in Qatar to reveal high Legionella counts in cooling towers
}

Raed O. AbuOdeh, ${ }^{1}$ Hassan A. Aziz, ${ }^{2}$ Houda Moussa, ${ }^{3}$ Samah Hussien, ${ }^{2}$ Tameem Hadwan ${ }^{2}$ and Gheyath K. Nasrallah ${ }^{2,4}$

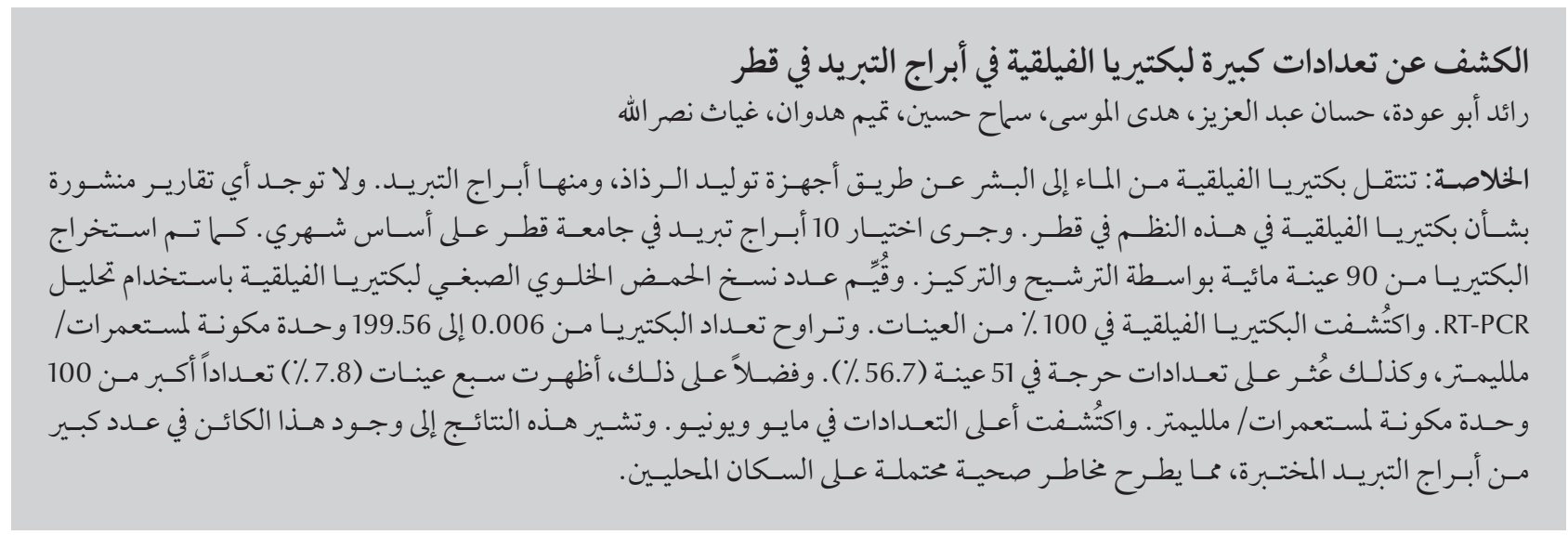

ABSTRACT Legionella spp. is transmitted from water to humans by aerosol-generating devices, including cooling towers (CTs). There have not been published reports about Legionella in these systems in Qatar. Ten CTs in Qatar University were sampled on a monthly basis. Bacteria were recovered from 90 water samples by filtration and concentration. Legionella DNA copy number $(\mathrm{CN})$ was assessed by quantitative RT-PCR. Legionella DNA was detected in $100 \%$ of the samples. The bacterial counts ranged from 0.006 to $199.56 \mathrm{CFU} / \mathrm{mL}$, and critical counts were found in 51 (56.7\%) samples. Moreover, 7 (7.8\%) samples showed a count of more than $100 \mathrm{CFU} / \mathrm{mL}$. The highest counts were found in the months of May and June. These results suggest that this organism is found in high number in tested CTs, presenting a potential health risk to the local population.

Première étude au Qatar pour mettre en évidence la forte présence de légionelles dans les tours de refroidissement

RÉSUMÉ Les Legionella spp se transmettent de l'eau à I'homme par les dispositifs générateurs d'aérosols, notamment les tours de refroidissement. Aucun rapport n'a été publié sur la présence de légionelles dans ces systèmes au Qatar. Des prélèvements mensuels ont été effectués dans dix tours de refroidissement de I'Université du Qatar. Des bactéries ont été retrouvées dans 90 échantillons d'eau par filtration et concentration. Le nombre de copies de I'ADN des Legionella a été évalué par PCR quantitative en temps réel. L'ADN des Legionella a été détecté dans $100 \%$ des échantillons. La numération bactérienne était comprise entre 0,006 et 199,56 CFU/mL et des numérations critiques ont été constatées dans 51 échantillons (56,7\%). En outre, 7 échantillons (7,8 \%) présentaient une numération supérieure à 100 CFU/mL. Les numérations les plus élevées ont été relevées aux mois de mai et de juin. Ces résultats semblent indiquer que cet organisme est présent en grand nombre dans les tours de refroidissement ayant fait l'objet de prélèvements, ce qui constitue un risque sanitaire potentiel pour la population locale.

'Department of Medical Laboratory Sciences, College of Health Sciences, University of Sharjah, Sharjah, United Arab Emirates. ${ }^{2}$ Academic Affairs, College of Arts and Sciences; ${ }^{3}$ Department of Biomedical Science, Health Sciences Department; ${ }^{4}$ Biomedical Research Center, Qatar University, Doha, Qatar(Correspondence to: Gheyath K. Nasrallah:gheyath.nasrallah@qu.edu.qa).

Received: 23/08/16; accepted: 24/01/17 


\section{Introduction}

Legionella pneumophila causes legionellosis (Legionnaires disease) and can be found in soil and in aquatic environments such as cooling towers $(1,2)$. This bacterium is an intracellular organism that naturally replicates inside amoebae, yet it can infect human alveolar macrophages (3) causing severe lung disease (4).

Cooling systems have been implicated in a great number of Legionnaires disease outbreaks (1) because of their capacity to disperse water aerosols over long distances $(5,6)$. Interestingly, human-to-human transmission has never been reported. The disease is mainly acquired through inhalation of contaminated water droplets $(1,6)$. Cooling towers provide optimum environmental conditions and protect the bacteria from disinfectants $(7,8)$. The temperature in the cooling tower can range from $20^{\circ} \mathrm{C}$ to $55^{\circ} \mathrm{C}(7)$, which favours growth of Legionella spp.

In Qatar, the summer season starts in May and lasts until September, with intense heat and humidity. Central cooling stations are widely distributed in Qatar, and many use open cooling towers. The only survey was conducted in 1990 to examine for the presence of Legionella in water systems (9) in a few buildings, many of which harboured Legionella spp. Nevertheless, there were no reported cases of legionellosis, although it is possible this may have been due to a lack of consistent laboratory testing for Legionella in local hospitals.

Water treatments using chemical biocides such as monochloramine or chlorine dioxide are commonly used to reduce the Legionella count in water $(1,10)$. Water testing of cooling towers is mandatory in many countries worldwide (11), and demands for standardized testing are increasing (12). Many international guidelines for water treatment consider a Legionella count of
$>10$ colony-forming units $(\mathrm{CFU}) / \mathrm{mL}$ critical (13).

In this study, the effectiveness of the water treatment protocol utilized at Qatar University campus was examined. We believe that cooling towers in Qatar University may be considered representative of other cooling towers in Qatar in the absence of studies in other sites.

\section{Methods}

\section{Sample collection}

We sampled 10 cooling towers in Qatar University (7 older technology and 3 new technology units) on a monthly basis during the period November 2013June 2014. No samples were collected in December, January or February because the cooling towers were not operating at full capacity during this time. Because biocide treatment is manually controlled for the old units, one or more samples (1L each) were collected 1,2,3 or 4 days post-treatment. Biocide treatment was automatically controlled for the new units, therefore only 1 sample of $1 \mathrm{~L}$ was collected and the units were only sampled during March, April and June.

\section{Sample concentration}

The water samples were concentrated by filtration through $0.45 \mu \mathrm{m}$ pore membranes (Water Microbial Concentration Kit, ielab, Spain). The membranes were then placed in a $50 \mathrm{~mL}$ tube containing $10 \mathrm{~mL}$ sterile water and vortexed vigorously for 2-3 minutes to release bacteria. The $10 \mathrm{~mL}$ concentrate was further concentrated to $200 \mu \mathrm{L}$ by centrifugation at $2200 \mathrm{~g}$ for $10 \mathrm{~min}$ using the concentrator cartridge (ielab kit); this was then transferred to a $1.5 \mathrm{~mL}$ tube and stored at $-80^{\circ} \mathrm{C}$ until DNA extraction.

\section{DNA extraction and quantitative real-time polymerase chain reaction (qRT-PCR)}

We extracted DNA from the water concentrates using the Water DNA Extraction Kit (ielab, Spain) according to the manufacturer's instructions. For detection and quantitation of the Legionella DNA copy number from the water concentrate, the mericon Quant Legionella spp qRT-PCR kit (Qiagen, Germany) was used. The kit contains primers that detect more than 19 common Legionella species with high sensitivity.

To convert the Legionella DNA copy number into approximate CFU/ $\mathrm{mL}$ values, the following formula was used: no. of CFU $/ \mathrm{mL}=$ no. of detected Legionella DNA copies/20 (14).

\section{Results}

Of the 90 samples collected, 51 (56.7 \%) showed a Legionella count greater than the critical level of $10 \mathrm{CFU} / \mathrm{mL}$ (range 10.2-199.56 CFU/mL) (Tables 1 and 2); the counts in 7 (7.8\%) samples were $>100 \mathrm{CFU} / \mathrm{mL}$. The remaining $39(43.3 \%)$ samples yielded counts ranging from 0.006 to $9.3 \mathrm{CFU} /$ $\mathrm{mL}$ (average $30.5 \mathrm{CFU} / \mathrm{mL}$ ).

The count in the old technology cooling tower units in November, March, April, May and June was 17.9 $\mathrm{CFU} / \mathrm{mL}$ (highest in May and lowest in November) (Table 1).

The 2005 Centers for Disease Control and Prevention protocol for monitoring Legionella in cooling towers recommends that water samples should be collected at least 3 days post-treatment (11). Accordingly, most water samples were collected 4 days post-biocide treatment.

Although the 7 cooling towers were all located in the same area and received the same treatment, there was a great difference in counts between cooling 


\begin{tabular}{|c|c|c|c|c|}
\hline Date & Cooling tower no. & DNA copy no./mL & $\mathrm{CFU} / \mathrm{ml}$ & Average count/month \\
\hline \multirow[t]{7}{*}{28 November } & 1 & 514.4 & $25.70^{\mathrm{a}}$ & 7.2 \\
\hline & 2 & 3.000 & 0.15 & \\
\hline & 3 & 186.6 & 9.33 & \\
\hline & 4 & 4.506 & 0.22 & \\
\hline & 5 & 52.59 & 2.63 & \\
\hline & 6 & 126.4 & 6.32 & \\
\hline & 7 & 120.0 & 6.00 & \\
\hline \multirow[t]{7}{*}{26 March } & 1 & 0.487 & 0.02 & 77.7 \\
\hline & 2 & 2080.5 & $104.00^{\mathrm{a}}$ & \\
\hline & 3 & 2232.7 & $111.60^{\mathrm{a}}$ & \\
\hline & 4 & 2290.4 & $114.50^{\mathrm{a}}$ & \\
\hline & 5 & 3123.7 & $156.10^{\mathrm{a}}$ & \\
\hline & 6 & 126.4 & 6.32 & \\
\hline & 7 & 1036.4 & $51.80^{\mathrm{a}}$ & \\
\hline \multirow[t]{7}{*}{17 April } & 1 & 933.4 & $46.70^{\mathrm{a}}$ & 34.1 \\
\hline & 2 & 1083.6 & $54.20^{\mathrm{a}}$ & \\
\hline & 3 & 265.0 & $13.30^{\mathrm{a}}$ & \\
\hline & 4 & 917.8 & $45.90^{\mathrm{a}}$ & \\
\hline & 5 & 985.5 & $49.30^{\mathrm{a}}$ & \\
\hline & 6 & 7.642 & 0.38 & \\
\hline & 7 & 592.6 & $29.60^{\mathrm{a}}$ & \\
\hline \multirow[t]{7}{*}{21 May } & 1 & 649.7 & $32.50^{\mathrm{a}}$ & 62.9 \\
\hline & 2 & 1030.9 & $51.50^{\mathrm{a}}$ & \\
\hline & 3 & 372.0 & $18.60^{\mathrm{a}}$ & \\
\hline & 4 & 839.8 & $41.90^{\mathrm{a}}$ & \\
\hline & 5 & 3991.3 & $199.50^{\mathrm{a}}$ & \\
\hline & 6 & 998.01 & $49.90^{\mathrm{a}}$ & \\
\hline & 7 & 931.1 & $46.60^{\mathrm{a}}$ & \\
\hline \multirow[t]{7}{*}{28 May } & 1 & 1163.0 & $58.20^{\mathrm{a}}$ & 41.3 \\
\hline & 2 & 690.0 & $34.50^{\mathrm{a}}$ & \\
\hline & 3 & 340.8 & $17.00^{\mathrm{a}}$ & \\
\hline & 4 & 555.3 & $27.70^{\mathrm{a}}$ & \\
\hline & 5 & 949.0 & $47.50^{\mathrm{a}}$ & \\
\hline & 6 & 1380.8 & $69.00^{\mathrm{a}}$ & \\
\hline & 7 & 702.3 & $35.10^{\mathrm{a}}$ & \\
\hline \multirow[t]{7}{*}{11 June } & 1 & 8.85 & 0.44 & 20.5 \\
\hline & 2 & 159.02 & 7.95 & \\
\hline & 3 & 0.754 & 0.04 & \\
\hline & 4 & 11.02 & 0.55 & \\
\hline & 5 & 13.47 & 0.67 & \\
\hline & 6 & 7.732 & 0.38 & \\
\hline & 7 & 5.944 & 0.29 & \\
\hline \multirow[t]{7}{*}{12 June } & 1 & 1027.2 & $51.40^{\mathrm{a}}$ & \\
\hline & 2 & 940.6 & $47.00^{\mathrm{a}}$ & \\
\hline & 3 & 267.7 & $13.30^{\mathrm{a}}$ & \\
\hline & 4 & 1634.56 & $81.70^{\mathrm{a}}$ & \\
\hline & 5 & 768.4 & $38.40^{\mathrm{a}}$ & \\
\hline & 6 & 922.5 & $46.10^{\mathrm{a}}$ & \\
\hline & 7 & 17.18 & 0.86 & \\
\hline
\end{tabular}




\begin{tabular}{|c|c|c|c|c|}
\hline Date & Cooling tower no. & DNA copy no./mL & $\mathrm{CFU} / \mathrm{mL}$ & Average monthly CFU/mL \\
\hline \multirow[t]{3}{*}{4 April } & N1 & 720.25 & $36.01^{*}$ & \multirow[t]{3}{*}{12.02} \\
\hline & N2 & 0.38 & 0.02 & \\
\hline & N3 & 0.75 & 0.04 & \\
\hline \multirow[t]{3}{*}{9 May } & N1 & 10.06 & 0.50 & \multirow[t]{3}{*}{13.01} \\
\hline & N2 & 190.51 & 9.53 & \\
\hline & N3 & 579.90 & $28.99 *$ & \\
\hline \multirow[t]{3}{*}{3 June } & N1 & 1191.71 & $59.59^{*}$ & \multirow[t]{3}{*}{62.74} \\
\hline & N2 & 1628.32 & $81.42^{*}$ & \\
\hline & N3 & 944.54 & $47.23^{*}$ & \\
\hline
\end{tabular}

$C F U=$ colony-forming units.

* Legionella spp. count $>10 \mathrm{CFU} / \mathrm{mL}$.

towers (Table 2). For instance, cooling tower 1 showed an average count (4 days after treatment) $25.3 \mathrm{CFU} /$ $\mathrm{mL}$, while cooling tower 5 showed an average count of $69.3 \mathrm{CFU} / \mathrm{mL}$. These results suggest that these cooling towers responded differently to treatment.

The average count in the new technology cooling tower units for AprilJune was 30.9 CFU/mL (Table 3); the highest count was for June and the lowest was for April, suggesting favourable growth conditions during the warmer months. The results indicate that although these cooling towers were new controlled, the count was still as high as in the old technology cooling towers.

\section{Discussion}

This study was the first of its kind to be conducted in Qatar. The detection of Legionella in water samples is and biocide injection was automatically

conventionally performed using a selective culture method (15), however, interference of background microorganisms may lead to false low counts (16), not to mention the necessary expertise in interpreting growth (14). Additionally, culture methods do not detect viable but nonculturable bacteria, which may also represent a health hazard (14). Despite these shortcomings, culture remains the method of choice. Other methods, such as qRT-PCR, can yield faster results and are highly sensitive and specific $(16,17)$. However, qRT-PCR has the disadvantage that it cannot differentiate between live and dead bacteria, therefore it may yield false high counts (15). In accordance with the universal standards for reporting Legionella counts (CFU/mL), qRTPCR results were converted to CFU/ $\mathrm{mL}$ (14).

Qatar has not established a standard for Legionella counts in cooling

\begin{tabular}{|c|c|}
\hline Cooling tower no. & Average monthly CFU/mL \\
\hline 1 & 25.3 \\
\hline 2 & 62.8 \\
\hline 3 & 33.2 \\
\hline 4 & 32.7 \\
\hline 5 & 69.3 \\
\hline 6 & 16.5 \\
\hline 7 & 24.6 \\
\hline
\end{tabular}

$C F U=$ colony-forming units. towers; however, according to international standards, a count greater than 10 $\mathrm{CFU} / \mathrm{mL}$ is considered a potential hazard requiring investigation. Since more than half of our samples demonstrated counts greater than $10 \mathrm{CFU} / \mathrm{mL}$, the overall count was relatively high.

The average counts in current results showed great fluctuation, therefore, each cooling tower should be considered a separate entity with its own unique micro-environment. Moreover, the monthly counts in the old and new technology units were noticeably high in May and June, which could be due to seasonal changes in weather. Fisman et al. reported that Legionnaires disease outbreaks occurred mainly in hot months, during humid periods (18). In May, the temperature and humidity increase remarkably in Qatar, marking the beginning of summer.

The biocide water treatment system in the new cooling tower units was supposedly more effective than in the old units. However, more than half of the new cooling tower samples had a count greater than $10 \mathrm{CFU} / \mathrm{mL}$ indicating that the automated method was also ineffective. As with the old cooling tower units, the counts were the greatest in the warm months.

To date, no outbreaks of Legionnaires disease have been reported in Qatar. This could be due to lack of investigation, making it an unrecognized pathogen. Pneumonia caused by 
Legionella is universally and clinically underestimated as the symptoms exhibited are very similar to pneumonia caused by other pathogens (19).

There were some limitations to this study. Samples were not collected in every month of the year and data were missed from 2 important hot months, September and October. Additionally, the sample size and the study was restricted to one area in Qatar. Thus, our findings may not be representative of the actual situation for Legionella counts in other regions or facilities in Qatar. Nevertheless, as this was the first such study in the country, we believe it provides valuable information on the current situation, and will stand a basis for comparison for future studies.

\section{Conclusion}

This study demonstrated that the overall Legionella count was very high in the cooling towers located in the Qatar University campus. Our findings raise concerns for public health officials in the control and management of cooling towers to prevent any potential cases or outbreaks. Further investigation is needed to determine the factors contributing to the increase in Legionella counts in the warmer months and the variations between cooling towers receiving the same treatment protocol.

\section{Acknowledgements}

Special gratitude goes to Maria Smatti, Enas Al-Absi, Rajaa Dalloul and Mooza Alkhinji for their technical help.

Funding: This research was funded by an Undergraduate Research Experience Program grant (\# UREP 15 - 014 - 3 005) from the Qatar National Research Fund (Qatar Foundation).

Competing interests: None declared.

\section{References}

1. Fields BS, Benson RF, Besser RE. Legionella and Legionnaires' disease: 25 years of investigation. Clin Microbiol Rev. 2002 Jul;15(3):506-26. PMID:12097254

2. Lin $\mathrm{H}, \mathrm{Xu} \mathrm{B}$, Chen $\mathrm{Y}$, Wang W. Legionella pollution in cooling tower water of air-conditioning systems in Shanghai, China. J Appl Microbiol. 2009 Feb;106(2):606-12. PMID:19120608

3. Allombert J, Fuche F, Michard C, Doublet P. Molecular mimicry and original biochemical strategies for the biogenesis of a Legionella pneumophila replicative niche in phagocytic cells. Microbes Infect. 2013 Dec;15(14-15):981-8. PMID:24161959

4. Fraser DW, Tsai TR, Orenstein W, Parkin WE, Beecham HJ, Sharrar RG, et al. Legionnaires' disease. N Engl J Med. 1977 Dec;297(22):1189-97. PMID:335244

5. Berendt RF, Young HW, Allen RG, Knutsen GL. Dose-response of guinea pigs experimentally infected with aerosols of Legionella pneumophila. J Infect Dis. 1980 Feb;141(2):186-92. PMID:7365275

6. Nhu Nguyen TM, Ilef D, Jarraud S, Rouil L, Campese C, Che $\mathrm{D}$, et al. A community-wide outbreak of Legionnaire's disease linked to industrial cooling towers-how far can contaminated aerosols spread? J Infect Dis. 2006 Jan;193(1):102-11. PMID:16323138

7. Carducci A, Verani M, Battistini R. Legionella in industrial cooling towers: monitoring and control strategies. Lett Appl Microbiol. 2010 Jan;50(1):24-9. PMID:19874487

8. Nasrallah GK, Abdelhady H, Tompkins NP, Carson KR, Garduño RA. Deletion of potD, encoding a putative spermidinebinding protein, results in a complex phenotype in Legionella pneumophila. Int J Med Microbiol. 2014 Jul;304(5-6):703-16. PMID:24928741

9. Utilities, conservation of resources and environmental control. Legionnaire's disease. [web page] Catnaps.org. (http://www. catnaps.org/islamic/control.html, accessed 23 May 2017).

10. Bodet C, Sahr T, Dupuy M, Buchrieser C, Héchard Y. Legionella pneumophila transcriptional response to chlorine treatment. Water Res. 2012 Mar;46(3):808-16. PMID:22192759
11. McCoy WF, Downes EL, Leonidas LF, Cain MF, Sherman $\mathrm{DL}$, Chen $\mathrm{K}$, et al. Inaccuracy in Legionella tests of building water systems due to sample holding time. Water Res. 2012 Jul;46(11):3497-506. PMID:22560149

12. Procedures for the recovery of Legionella from the environment. Atlanta: Centers for Disease Control and Prevention; 2005.

13. Important factors for assessing risk. Legionella in My Water. Special Pathogens Laboratory. Pittsburgh No date

14. Yáñez MA, Nocker A, Soria-Soria E, Múrtula R, Martínez L, Catalán V. Quantification of viable Legionella pneumophila cells using propidium monoazide combined with quantitative PCR. J Microbiol Methods. 2011 May;85(2):124-30. PMID:21329735

15. Ditommaso S, Giacomuzzi M, Gentile M, Moiraghi AR, Zotti CM. Effective environmental sampling strategies for monitoring Legionella spp. contamination in hot water systems. Am J Infect Control. 2010 Jun;38(5):344-9. PMID:20083326

16. Park CG, Kim BJ, Kim HY, Yun YJ, Ko KS, Miyamoto H, et al. Analysis of population structure among Korean and Japanese Legionella pneumophila isolates using hsp60 sequences. Microbiol Immunol. 2012 Aug;56(8):572-8. PMID:22672106

17. Mansi A, Amori I, Marchesi I, Marcelloni AM, Proietto AR, Ferranti $G$, et al. Legionella spp. survival after different disinfection procedures: Comparison between conventional culture, qPCR and EMA-qPCR. Microchem J. 2014 Jan;112:65-9.

18. Fisman DN, Lim S, Wellenius GA, Johnson C, Britz P, Gaskins $M$, et al. It's not the heat, it's the humidity: wet weather increases legionellosis risk in the greater Philadelphia metropolitan area. J Infect Dis. 2005 Dec;192(12):2066-73. PMID:16288369

19. Walser SM, Gerstner DG, Brenner B, Höller C, Liebl B, Herr CEW. Assessing the environmental health relevance of cooling towers - A systematic review of legionellosis outbreaks. Int J Hyg Environ Health. 2014 Mar;217(2-3):145-54. PMID:24100053 